\title{
Non-nominal arguments and transitivity in Romance and Scandinavian ${ }^{1}$
}

\author{
Michelle Sheehan
}

Anglia Ruskin University

\author{
Anna Pineda \\ Universitat Pompeu Fabra, Barcelona
}

\begin{abstract}
This squib considers the notion of objecthood and its relation to transitivity in a number of Romance and Scandinavian languages and argues that it does not easily reduce to the notion of being nominal. The Romance data come from the faire-infinitive in Catalan and Italian, where dative causees are found only where the embedded predicate is transitive. The Scandinavian data are from pseudo-passives and expletive-associate constructions, both of which are also sensitive to transitivity. In these contexts, in addition to DPs, (non-nominalised) CPs and PPs can count for transitivity, though this is subject to variation across languages. These patterns present challenges for approaches to objecthood and transitivity based on case/Case, both traditional analyses and more recent dependent case approaches, both of which afford a privileged status to nominals.
\end{abstract}

1 This paper was inspired by Sten Vikner in three different ways. First, we offer it as a simple token of our respect for him and his work on the occasion of his $60^{\text {th }}$ birthday. Second, it was directly inspired by the questions he asked at a talk we gave at University of Cambridge on this topic. Finally, it is more generally inspired by Sten's wonderful careful comparative syntactic work which serves as a model of methodical comparison for all scholars of language.

Ken Ramshøj Christensen, Henrik Jørgensen \& Johanna L. Wood (eds.). 2019.

The Sign of the V-Papers in Honour of Sten Vikner.

Dept. of English, School of Communication \& Culture, Aarhus University, pp. 573-590, doi:10.7146/aul.348.110. (C) The author(s). 


\section{Introduction}

In both traditional and recent approaches to objecthood and transitivity, DPs are considered to have a privileged status, distinct from other categories. In early generative approaches, based on their different distribution from clauses and prepositional phrases (PPs), DPs, it was claimed, require licensing by Case, unlike PPs and CPs (Chomsky 1981, Stowell 1981). This basic idea is retained in recent approaches to case, notably dependent case theory (Marantz 1991, Baker 2015 and many others). The core idea of the dependent case approach is that morphologically overt cases are assigned in contexts where two DPs are found in a local configuration, potentially to aid differentiation of the two arguments. This kind of analysis is particularly appealing as an account of transitivity-sensitive morphological cases, such as dative in the Romance faire-infinitive (see Folli \& Harley 2007, Pitteroff \& Campanini 2013).

In this squib, we note that although dative case in the faire-infinitive is indeed a transitivity-sensitive case, it is triggered not only by DPs but also by CPs and, in some cases, PPs. We then turn to data from pseudo-passives and expletive-associate constructions in Scandinavian languages, which are also transitivity-sensitive, where $\mathrm{CPs} / \mathrm{PPs}$ again sometimes count for transitivity. Section 2 introduces the faire-infinitive. Section 3 describes the behaviour of CP and PP objects in this context. Section 4 extends the discussion to the Scandinavian patterns. Section 5 outlines the problems these patterns pose for case/Case theory. Finally, Section 6 concludes and raises some questions for future research.

\section{Background: transitivity in causative contexts}

In many Romance languages (e.g., French, Italian, Catalan, European Portuguese) causees surface with dative case in the faire-infinitive construction only where the embedded predicate is transitive (Kayne 1975, Burzio 1986, amongst others), as exemplified here for Italian:

(1) Gianni gli/*l' ha fatto lavare i piatti. [Italian] Gianni him.DAT $/ *_{A C C}=$ has made wash.INF the dishes 'Gianni made him wash the dishes.'

Conversely, where the embedded predicate is intransitive, dative is not (generally) available in these languages. Thus, in Italian (2) and Catalan 
(3), where the embedded predicate is parlare/parlar 'speak', the causee is obligatorily accusative for the speakers we have consulted: ${ }^{2}$

$\begin{array}{llll}\mathbf{L} / * \text { gli } & \text { ho } & \text { fatto } & \text { parlare. } \\ \text { him.ACC } / *_{D A T}= & \text { I.have made } & \text { talk.INF }\end{array}$

[Italian]

'I made him talk.'

$\begin{array}{llll}\mathbf{L} / * \mathbf{l i} & \text { he } & \text { fet } & \text { parlar. } \\ \text { him.ACC }{ }^{*} D A T= & \text { I.have } & \text { made } & \text { talk.INF } \\ \text { 'I made him talk.' } & & & \end{array}$

[Catalan]

This is what we will call a transitivity-sensitive case pattern: dative is possible only in transitive contexts. In the particular case of Catalan, this pattern may be obscured by: (i) Exceptional Case Marking (ECM) where clitics are involved (Solà 1994:\$9.3, Torrego 1998:§3); and (ii) differential object marking (DOM) where full DPs rather than clitics are involved (though this is proscribed in standard Catalan and therefore stylistically marked, e.g. Alsina 2016: 380). In relation to the former, our survey data confirm that a significant minority of speakers allow ECM with fer 'make' so that transitive subjects like the one in (1) can also be accusative for some Catalan speakers (4). ECM is not possible with full DPs, however, for any speakers. This, we attribute to the fact that ECM requires raising to object and, in some languages, this is only possible with clitics (see Sheehan 2019):

\% $\mathbf{L}$ ' he fet escombrar el menjador.
him.ACC I.have made sweep.INF
'I have made him sweep the dining room.'

$[10 / 25$ speakers $]$

DOM obscures the pattern with intransitive causees when they are full DPs (rather than clitics, as in (2)-(3)). The availability of DOM means that accusative DP causees can optionally be introduced by $a$ in Catalan (5), in contrast with (Northern) standard Italian (6): ${ }^{3}$

2 Our sincere thanks to Norma Schifano for help collecting the Italian data. Rita Manzini (personal communication) notes that dative is available for her even in intransitive contexts. This pattern is also found in many Spanish varieties, as noted below. In such contexts, dative is clearly no longer sensitive to transitivity.

3 Note that Southern Italian speakers often allow DOM, which again complicates the picture and introduces one of the confounds we discuss for Catalan. 
(5)

$\begin{array}{llllll}\text { El psicòleg } & \text { va fer } & \text { parlar } & \text { (a) la } & \text { Maria. } \\ \text { the psychologist } & \text { made.3SG } & \text { talk.INF } & \text { (DOM) } & \text { the } & \text { Maria }\end{array}$

'The psychologist made Maria talk.'

[no DOM=42/57,

$\mathrm{DOM}=44 / 57]$

(6) Ho fatto parlare (*a) Gianni.

I.have made talk.INF DOM Gianni

'I made Gianni talk.'

Our survey data show that the further away a causee is from fer, the more likely it is to receive DOM in Catalan. We attribute this to a processing effect. Once we control for these factors, both Italian and Catalan are ultimately like French and European Portuguese in having transitivitysensitive dative causees and unlike many Spanish varieties which also permit dative causees in intransitive contexts (Company 2003, Ordóñez \& Roca 2017).

\section{Non-nominal arguments and transitivity in Romance}

Thus far we have shown that dative case in Romance faire-infinitive causatives is sensitive to transitivity in Italian and Catalan. That is, we have seen that whenever the embedded verb has a DP internal argument, the causee will/can be marked dative, whereas if there is no internal argument, the causee must bear accusative case. In this section, we consider what happens when the embedded verb has a non-nominal complement, namely a CP or PP complement. Do such contexts count as transitive or intransitive in terms of the case which surfaces on the causee?

\subsection{Clausal complements}

With respect to clausal complements, in both Italian and Catalan, finite and non-finite CP complements obligatorily count for transitivity, always triggering dative on the causee. This is easy to show for Italian, where all clausal complements of non-restructuring verbs behave alike, regardless of mood, finiteness, or the kind of subordinator (zero, di, $a, c h e$ ):

$$
\begin{array}{lllll}
\text { Le/*la } & \text { fecero } & \text { promettere } & {[\mathrm{di}} & \text { cantare }] . \\
\text { her.DAT } / *_{A C C} & \text { made.3PL } & \text { promise.INF } & \text { of } & \text { sing.INF }
\end{array}
$$

'They made her promise to sing.' 
(8) Gli $/{ }^{*} \mathbf{L}$ hanno fatto pensare [che si sbagliava]. him.DAT/*ACC $=$ have.3PL made think.INF that REFL was.wrong 'They made him think he was wrong.'

Catalan is more complex. Firstly, many Catalan speakers strongly prefer the predicate which is the complement of fer to take a finite complement here, even where these same predicates accept a non-finite complement elsewhere. In such contexts, dative is the most widely accepted option, with accusative only being possible for the subset of speakers who permit ECM with fer:

$\mathbf{L i} / \% \mathbf{L}$ han fet prometre [que cantaria]. him.DAT/\%ACC $=$ have. $3 P L$ made promise.INF that would.sing. $3 S G$ 'They made her promise to sing'.

Where speakers do allow the embedded non-restructuring verbs to take a non-finite complement, dative is again generally accepted (10) (again modulo the availability of ECM for some speakers), as in Italian (7)-(8):

$\begin{array}{lllll}\text { Li/\%l' } \% \text { han } & \text { fet admetre } & \text { [haver } & \text { mentit] } \\ \text { him.DAT/\%ACC } & \text { have.3PL made admit.INF } & \text { have.INF } & \text { lied } \\ \text { 'They made him admit he had lied.' } & & & \end{array}$

With restructuring verbs, like començar 'start', however, DAT becomes possible in both languages only where the complement of the most embedded verb is transitive (11b). We illustrate this only for Catalan here, but Italian is broadly speaking the same (see Sheehan and Pineda 2019):

a. $[\ldots] \mathbf{l}^{\mathbf{1} / *}$ li han fet començar a plorar a mitja classe. her.ACC ${ }^{*}$ DAT $=$ have.3PL made start.INF to cry.INF in half class 'They made her start crying in the middle of the class.'

b. $\%[\ldots]$ li/l' ' han fet començar a escriure una queixa. him.DAT/ACC $=$ have.3PL made start.INF to write.INF a complaint 'They made her start writing a complaint.' [DAT=33/57, $\mathrm{ACC}=24 / 57]$

Essentially, such examples are optionally monoclausal: clause union between 'make' and its complement (and thus clitic climbing of the 
causee) is forced, whereas restructuring is optional between 'start' and its complement. Where restructuring takes place, the case of the causee is determined by the transitivity of the next clause down. Crucially, where no restructuring takes place, the clausal complements of these restructuring verbs cannot trigger dative, and so do not behave like full CPs. If the clausal complements of restructuring predicates were CPs, then dative causees would be acceptable also in examples like (11a), contrary to fact. The implication is that only complete clausal complements count for transitivity. With restructuring clausal complements which are presumably smaller than CP, the embedded predicate counts as intransitive. These facts show that the notion of transitivity which is relevant here is more nuanced than is often thought and is not easily accommodated under theories of case/Case which connect transitivity to the presence of a local DP.

\subsection{PP complements}

This impression is reinforced when we consider the behaviour of PP arguments. For many Catalan speakers, PP arguments can also count for transitivity, triggering dative case on causees, but with substantial interspeaker variation (12). The same is not true of Italian, where PP complements do not seem to count for transitivity in the same way (13).

$\begin{array}{llll}\text { Com que el professor } \quad \mathbf{l a} / \% \mathbf{l i} & \text { va fer } & \text { parlar } \\ \text { since } & \text { the teacher } \quad \text { her.ACC/\%DAT } & \text { made.3SG } & \text { talk.INF } \\ \text { dels seus problemes, }[\ldots] & & \\ \text { of.the her problems } & & & \end{array}$

'Since the teacher made her talk about her problems, $[\ldots]$ '

$$
[\mathrm{acc}=45 / 57, \text { dat }=21 / 57]
$$

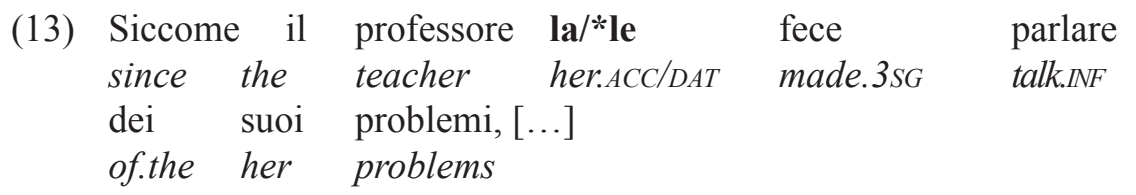

'Since the teacher made her talk about her problems, $[\ldots]$ '

This variation recalls the fact that DP objects with inherent case count for transitivity in some ergative languages, but not others (Legate 2012, Baker 2015 ), though the interspeaker variation is problematic. For example, in our Catalan survey, 21/57 speakers accepted the dative in (12) and 45/57 the accusative. This is the opposite pattern to that usually attested in transitive 
contexts featuring a DP object, in which almost all speakers accept dative and a substantial minority also accept accusative (due to ECM). Rather, it seems that for many Catalan speakers, the context in (12) is treated as intransitive, with only a minority allowing the PP complement to count for transitivity.

What (12) seems to indicate is that argumental PPs (such as dels seus problems 'about her problems') count for transitivity for a large minority of Catalan speakers. This is true only of argument PPs; non-argumental PPs (such as durant més de dues hores 'for more than two hours') do not count for transitivity, and so are incompatible with DAT for all speakers:

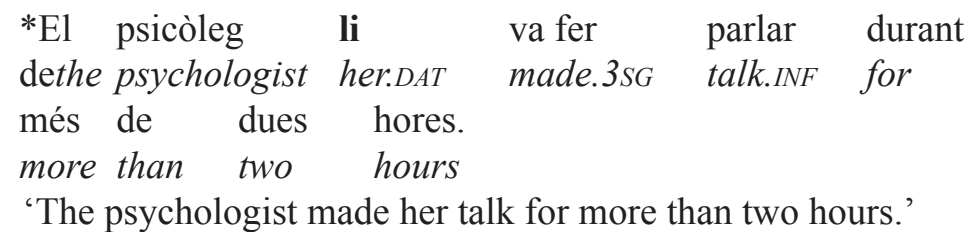

Note that, so far, we have given examples containing cliticised causees, since using DP causees would obscure the facts, due to the availability of DOM for many Catalan speakers, as discussed above (see (5)). The possibility of having dative causees with argumental PPs is also discussed by Villalba (1992: 362-365), when dealing with word order issues in Catalan causatives. Villalba does not take DOM into consideration, as it is banned from standard Catalan. Thus, when he gives an example of a DP preceded by $a$, such as (15a), he takes it to be a dative argument. Crucially, when dative is banned because the argumental PP is not intervening (15b), Villalba considers ungrammatical the use of $a$. The example would be fine for speakers using DOM, though, as already noted, this is not accepted in standard Catalan. In sum, in (15a) $a$ is necessary, otherwise the sentence is ungrammatical. This suggests that causees surfacing to the right of a PP complement either must obligatorily take DOM, or be headed by the dative marker $a$.

$$
\begin{aligned}
& \text { a. Farem creure/confiar en l' atzar *(a) } \\
& \text { will.make.1PL believe/rely.INF in/on the chance to/DOM } \\
& \text { la Maria. } \\
& \text { the Mary } \\
& \text { 'We shall make Mary believe in/rely on chance.' }
\end{aligned}
$$



b. Farem creure/confiar (*a) la Maria en will.make.1PL believe/rely.INF to/DOM the Mary in/on l' atzar. the chance
'We shall make Mary believe in/rely on chance.'

(Villalba 1992: 364)

Examples parallel to (15a) with full DP causees were also tested in our survey. The results show that $a$ marking is strongly preferred in such examples. Example (16) is accepted by 53/57 speakers:

El psicòleg va fer parlar dels seus problemes
the therapist made.3SG talk.INF of.the her problems
a $\quad$ la Maria.
to/DOM the Maria
'The therapist made Maria talk about her problems.'

As can be seen, we gloss $a$ in (15)-(16) as either a dative marker or DOM, as speakers vary on how they treat it. As we saw in (12), there is a group of speakers who can replace the causee a la Maria with a dative clitic, thus indicating that the argumental PP counts for transitivity making the causee a dative argument; we also saw that many speakers also like, or prefer, to replace a la Maria with an accusative clitic, thus indicating that this is a differentially-marked accusative argument.

In fact, $a$ is preferred on causees in Catalan whenever any material intervenes between the embedded verb and the causee; more speakers accepted (17) with $a(53 / 57)$ than without (38/57) and this example involves a non-argumental PP. In this case, $a$ is not a dative marker, but DOM. This is shown by the fact that the vast majority of speakers (47/57) rejected the corresponding sentence with the causee represented by a dative clitic, as shown in (14) above. This suggests that $a$ is generally treated as DOM in examples such as (17) rather than dative marking.

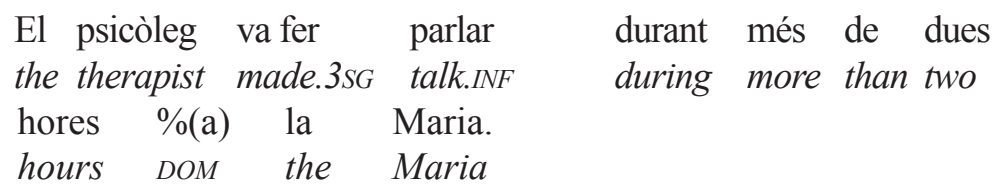

'The therapist made Maria talk for more than two hours.' 
So the facts in Catalan are complex but it seems clear that, for a sizeable minority of speakers, PP complements also count for transitivity, whereas this is not true in Italian.

So far we have seen that $\mathrm{CP}$ and PP complements may count for transitivity in Romance causatives, raising challenges for traditional accounts of transitivity connected to case/Case. Before stating more clearly what these challenges are, we first show that similar issues arise in Scandinavian languages, drawing on work by Vikner. This suggests that this is a more general fact about European languages.

\section{Non-nominal arguments and transitivity in Scandinavian}

In this section, we show that non-nominal arguments also appear to count for transitivity to varying degrees in Danish, and possibly also Norwegian and Swedish in pseudo-passives/expletive-associate constructions.

\subsection{CP complements}

Vikner (1995:246; 2017:381-383) argues that CPs also count for transitivity in Danish. The evidence for this comes from the behaviour of pseudo-passives which are permitted in Norwegian and Swedish with DP complements of P (as in English), but not in Danish (Vikner 1995: 246, citing Herslund (1984:70, fn. 7):

$$
\begin{aligned}
& \text { *... at Peter blev grinet af } \mathrm{t}_{\mathrm{i}} \\
& \text { that Peter was laughed at } \\
& \text { '...that Peter was laughed at.' }
\end{aligned}
$$

(Vikner 1995:246)

To account for this contrast, Vikner proposes that, in Norwegian and Swedish (like English), prepositions do not assign case to their complements, whereas in Danish they do. For this reason, when the verb loses the ability to assign accusative case (in passive contexts), the complement of a preposition can be promoted to subject in Norwegian and Swedish (and English) but not Danish. Vikner notes, however, that impersonal passives are possible with verbs selecting a PP complement in Danish as long as the preposition selects a $\mathrm{CP}$, as in (19). In such contexts, the subject is a nonthematic 'there' expletive der. It follows then that in (19) the preposition with must assign accusative to its $\mathrm{CP}$ complement, suggesting that $\mathrm{CPs}$ participate in the case system. Note that Danish has impersonal passives, 
and so allows passivisation of intransitive verbs, unlike English (see below on the behaviour of CPs in English passives):

(19) ... at *det/der blev regnet med [at du ville komme]

[Danish]

... that it/there was counted with that you would come

'... that $*$ it/there was counted on [that you would come]'

(Vikner 1995:247)

Vikner proposes, furthermore, that the expletive der 'there' is assigned NOM as the subject of a finite clause. This leads to a well-formed sentence because the non-thematic 'there' expletive in (19) simply absorbs nominative case. Note that the 'it' expletive det is not possible in (19). In Vikner's terms this is because this kind of quasi-thematic expletive would be base generated with the CP clause, reciving accusative case. Moving it to subject position therefore leads to a situation in which the same pronominal element has both accusative and nominative case and this leads to ungrammaticality.

Vikner further notes that these kinds of examples are also well-formed if the CP is topicalised, as long as der 'there' still occupies the subject position:

(20) [At du ville komme $]_{\mathrm{i}}$ blev der regnet med $\mathrm{t}_{\mathrm{i}}$ [Danish] that you would come was there counted with

'That you would come was counted on.'

(Vikner 1995:249, translation added)

On the other hand, (21) is ill-formed. This again falls out if the CP receives accusative case from the preposition as this would prevent it from transiting through the (nominative) subject position on the way to the initial topic position. Danish has a strong EPP requirement and overt expletives, so the subject position in (21) must be taken to contain a trace/copy of the CP, Vikner claims.

(21) * [At du ville komme $]_{\mathrm{i}}$ blev $\mathrm{t}_{\mathrm{i}}$ regnet med $\mathrm{t}_{\mathrm{i}}$ [Danish] that you would come was counted with

'That you would come was counted on.'

(Vikner 1995:243, translation added) 
As Vikner shows, the Norwegian and Swedish versions of (21) are well formed: see (22), where pseudo-passive is possible, and the trace/copy thus does not receive ACC in the complement-of-P-position, but only NOM by moving through the subject position:

(22) a. [At du ville komme $]_{\mathrm{i}}$ blev $\mathrm{t}_{\mathrm{i}}$ regnet med $\mathrm{t}_{\mathrm{i}}$ [Norwegian] that you would come was counted with 'That you would come was counted on'

b. [Att du skulle komma] räknades $t_{i}$ med $t_{i}$ [Swedish] that you would come counted.PASS with

'That you would come was counted on'

(Vikner 1995:251, translations added)

Taken together, Vikner claims that these patterns suggest that CPs are assigned case in Danish, Swedish and Norwegian. The evidence is most compelling for Danish, but the contrasts between Danish and Norwegian/ Swedish follow if CPs have case in all three languages and what differs is the ability of prepositions to assign case (in passive contexts).

Further evidence for this claim in relation to Danish comes from the behaviour of complements of adjectives. As Stowell (1981) pointed out, in English, while nominal complements of adjectives and nouns must be introduced by a preposition, CP complements need not. In Danish, however, $\mathrm{CP}$ complements of adjectives must also be introduced by a preposition (Sten Vikner, p.c.):
a. Henrik er misundelig * (på) dem. Henrik is envious on them
'Henrik is envious of them.'

b. Henrik er misundelig* (over) at de er glade. Henrik is envious over that they are happy 'Henrik is envious that they are happy.'

This suggests that in Danish, CPs have a more nominal status than in English. In fact, the Danish facts in particular raise potential challenges for traditional approaches to case/Case, as we discuss in section 5. The parallel with the Romance facts is obvious: in both cases CPs look like DPs in terms of their syntactic behaviour. 


\subsection{PP complements}

In Mainland Scandinavian, in addition to unaccusative verbs, unergative verbs can appear with an expletive subject. The use of the auxiliary har 'has' shows that that 'dance' is an unergative verb:

... at der har danset nogen i haven that there has danced someone in garden.DEF

'...that someone has danced in the garden.'

(Vikner 1995:203, translation added)

Expletives are not possible with transitive verbs and the Danish data in (25b) show that they are also banned with verbs which select a PP complement. This can be contrasted with examples like (25a), which contain a PP adjunct, and which are fully acceptable:

a. Der dansede mange mennesker til festen

[Danish] there danced many people at party.DEF

'Many people danced at the party.'

b. *Der snakker mange folketingsmænd med journalister hver dag there talk many congressmen with journalists every day 'Many MPs talk to journalists every day.'

(Vikner 1995:205)

The ungrammaticality of (25b), as compared with (25a), suggests that the selected PP in (25b) counts for transitivity, replicating the patterns observed in Catalan above. Once again, then, Danish behaves like Catalan in terms of the behaviour of its non-nominal arguments.

\section{Discussion}

Our discussion of Romance and Scandinavian languages has established that CPs generally count for transitivity and that certain kinds of PPs also do so in some languages. This poses obvious challenges for case/Case theory both in its traditional instantiation and in more recent dependent case approaches. We briefly review these problems here but stop short of proposing an alternative account of the patterns.

Traditional Case theory holds that DPs, unlike CPs, PPs and reduced predicative nominals, require Case licensing. While there are many different formulations of this idea, the dominant minimalist view is that 
Case is an uninterpretable feature which needs to be valued during the course of the derivation. Even in a model which allows default valuation for other features, it has been argued that Case is what Preminger (2014) termed a 'derivational time-bomb', a feature which, if not valued, will lead to a derivational crash. If this feature is taken to be a feature of D (realised morphologically in many languages), then it is not expected to be required by CP/PP arguments, or even (predicative) nominals lacking a D-layer. Indeed, Case theory was developed in order to account for the differing distributions of DPs vs. other arguments, as documented by Stowell (1981). In English, for example, as noted above, categories such as adjectives require nominal complements to be introduced via a preposition, whereas CP/PP complements need not (in contrast with the pattern observed in Danish above). A crucial aspect of Agree-based Case theory is the activity condition, which requires DPs to bear a Case feature in order to be active and able to participate in phi-feature valuation. Empirically, this is grounded in the observation that Case and phi-feature valuation often go hand in hand, especially in European languages.

So how can we deal with the facts discussed here? It is possible to stipulate, of course, that in some languages $\mathrm{C}$ and $\mathrm{P}$ also bear unvalued Case features. As we have seen, there is some evidence for this is Danish where $\mathrm{CP}$ complements of adjectives must also be introduced by a preposition. If this preposition is there for case-related reasons, then it can be taken as evidence that CPs require Case and we can model variation across language by simply parameterising the distribution of unvalued Case features. The same could be said for Catalan. Inherently reflexive verbs like acostumar$s e$ 'to get used to' and queixar-se 'to complain' cannot combine with a DP complement, presumably because they cannot assign accusative case (see Zaring 1992 for a parallel discussion of French):

$$
\begin{aligned}
& \text { a. Es va acostumar *(a) la seva manera de fer. } \\
& \text { REFL get.used.PST.3SG to the her way } \\
& \text { 'He got used to her manners' }
\end{aligned}
$$

b. Es queixava *(de) el seu comportament. REFL complain.IPFV.3SG of the their behaviour 'He complained about their behaviour'

In standard Catalan, $\mathrm{CP}$ complements of these verbs are not introduced by a preposition: 
a. No s' acostuma $\quad$ que li parlin $\begin{gathered}\text { anglès. } \\ \text { [Standard Cat.] }\end{gathered}$
no REFL get.used.PRS.3SG that to.him talk.SBJV.3PL English 'He does not get used to people talking to him in English'

b. Es queixava que li parlaven anglès. REFL complain.IPFV.3SG that to.him talk.IPFV.3PL English 'He complained that people talked to him in English'

However, in colloquial Catalan, these CP complements also tend to be introduced by the preposition $a$ :

a. No s' acostuma

a que li parlin

anglès.

[Coll. Cat.]

no REFL get.used.PRS.3SG to that to.him talk.SBJV.3PL English

'He does not get used to people talking to him in English'

b. Es queixava de que li parlaven anglès. REFL Complain.IPFV.3SG of that to.him talk.IPFV.3PL English 'He complained that people talked to him in English'

This suggests that for many Catalan speakers, these CPs are treated essentially like DP arguments. This cannot be the whole truth, however. CPs count for transitivity in the faire-infinitive also in Italian and French where the equivalents to (28a-b) are ungrammatical, as far as we have been able to ascertain.

In more recent approaches to case, and in particular transitivity, an alternative analysis has become popular in terms of dependent case. Though this approach is not all that new (see Anderson 1976, Yip, Maling \& Jackendoff 1987, Marantz 1991) it has become increasingly popular in recent years (see McFadden 2004, Baker \& Vinokurova 2010, Baker 2015, Levin \& Preminger 2015, Nash 2017). The crucial claim of such approaches is that overt morphological case is triggered not via a dependency between a DP and a functional head, but by the presence of two DPs in a local domain. In Baker's (2015) phase-based approach, where two DPs are spelled out in the same phase, the higher, the lower, or, in some cases, both receive a special morphological marking, labelled 'case'. The facts presented here also pose a challenge for this approach. While Baker discusses instances where PPs count as 'case competitors', he is explicit in stating that the dependent case approach does not expect non-nominalised CPs to count for transitivity in the same way, as non-nominalised CPs are 
never recipients of case (Baker 2015: 197). The challenge posed by these Romance and Scandinavian facts therefore carries over to this approach. In essence, the challenge is the same. For CPs to be nominal and count as case competitors, they should also behave like DPs in other ways, and while this may be true in Danish and to some extent Catalan, it is not always the case. There are instances where CPs and PPs count for transitivity without obviously being recipients of case/Case and stipulating that they are in some way nominal is at best a restatement of the observation and at worse an account which makes incorrect predictions for other aspects of the grammar.

In fact, the fact that CPs and PPs can count for transitivity is not limited to Romance and Scandinavian languages. We have mentioned that PPs can sometimes count as case competitors, as this is also discussed by Baker (2015). The fact that CPs can count for transitivity is also something that is observed beyond these two language families. As Bárány and Sheehan (2019) note, the same is true of Tsez (citing Polinsky and Potsdam 2001). Even in English, passivisation (which is transitivity-sensitive) is possible with some verbs selecting a CP complement, but not all (see Sheehan 2011):

a. ??It was whinged/complained that it would rain

b. It was hoped/wished that it would rain.

The verbs in both (29a) and (29b) require nominal but not CP arguments to be contained in a PP.

(30) a. She whinged/complained *(about) the weather

b. She hoped/wished *(for) a better life.

This suggests that the CPs in (29b) cannot be straightforwardly nominal, or we would expect to see a preposition if this were the case. Sheehan (2011) shows, however, that the verbs in (29b), unlike those in (29a) can surface with the 'special pronoun' something which replaced a CP complement (see Moltmann 2009):

(31) a. *She whinged/complained something.

b. She hoped/wished something. 
We are therefore left with a more nuanced picture whereby whether $\mathrm{CP} / \mathrm{PP}$ arguments count for transitivity is parameterised and variable, with some CPs displaying some nominal properties. Whether this can be captured by a version of case theory depends on how flexible one is willing to make that theory and whether an alternative, more explanatory account of these patterns can be found.

\section{Conclusions}

In this squib, we have briefly explored what it means to be transitive in some Romance and Scandinavian languages. Contrary to what is expected given different versions of case theory, including the dependent case approach, DPs do not have a privileged status in this regard. In Italian, Catalan, Danish, Swedish and Norwegian CPs can count for transitivity. In Catalan and Danish, the same can be said of PP complements. These facts, which are not limited to the languages under discussion, show that there is still much to discover about transitivity and how best to model it. More specifically, case theory, even in its dependent case instantiation, is not yet fully able to account for these patterns. Further study is needed of transitivity-sensitive phenomena in other language families to ascertain to what extent CPs and PPs count for transitivity at a broader cross-linguistic level.

\section{References}

Alsina, Àlex. 2016. 'Catalan'. In Adam Ledgeway and Martin Maiden (eds.), The Oxford Guide to the Romance Languages, 363-381. Oxford: Oxford University Press.

Anderson, Stephen R. 1976. On the notion of subject in ergative languages. In Charles N. Li (ed.), Subject and Topic, 1-24. New York: Academic Press.

Baker, Mark C. \& Nadya Vinokurova. 2010. Two modalities of case assignment. Natural Language \& Linguistic Theory 28. 593-642. https://doi.org/10.1007/ s11049-010-9105-1.

Baker, Mark C. 2015. Case: Its principles and its parameters. Cambridge: Cambridge University Press.

Bárány, András and Michelle Sheehan. 2019. When dependent case is not enough. Main colloquium, GLOW, Oslo, May 2019.

Burzio, Luigi. 1986. Italian Syntax. Dordrecht: Kluwer. 
Chomsky, Noam. 1981. Lectures on government and binding. Dordrecht: Foris Publications.

Company, Concepción. 2003. Transitivity and grammaticalization of object. The struggle of direct and indirect object in Spanish. In Giuliana Fiorentino (ed.), Romance objects. Transitivity in Romance languages, 217-260. Berlin-New York: Mouton de Gruyter.

Folli, Raffaella \& Harley, Heidi. 2007. Causation, obligation, and argument structure: On the nature of little v. Linguistic Inquiry 38. 197-238. https://doi. org/10.1162/ling.2007.38.2.197.

Herslund, Michael. 1984. Particles, prefixes and preposition stranding. In Finn Sørensen \& Lars Heltoft (eds.), Topics in Danish syntax, 34-71. Copenhagen: Akademisk Forlag.

Kayne, Richard S. 1975. French syntax. Cambridge, Mass: MIT Press.

Legate, Julie Anne. 2012. Types of ergativity. Lingua 122. 181-191. https://doi. org/10.1016/j.lingua.2011.10.014.

Levin, Theodore \& Omer Preminger. 2015. Case in Sakha. Natural Language \& Linguistic Theory 33. 231-250. https://doi.org/10.1007/s11049-010-9105-1.

Marantz, Alec. 1991. Case and Licensing. In Germán F. Westphal, Benjamin Ao \& He-Rahk Chae (eds.), Proceedings of the 8th Eastern States Conference on Linguistics (ECOL), 234-253. Columbus, Ohio: Ohio State University.

McFadden, Thomas. 2004. The position of morphological case in the derivation. University of Pennsylvania $\mathrm{PhD}$ dissertation.

Moltmann, Friederike. 2009. Attitudinal Objects. Unpublished ms., Paris: IHPST.

Nash, Léa. 2017. The structural source of split ergativity and ergative case in Georgian. In Jessica Coon, Diane Massam \& Lisa deMena Travis (eds.), The Oxford handbook of ergativity, 175-200. Oxford: Oxford University Press.

Ordóñez, Francisco \& Francesc Roca. 2017. Causativas y leísmo generalizado en dialectos del español. Relaciones sintácticas. Bellaterra: UAB, Servei de Publicacions.

Pitteroff, Marcel \& Cinzia Campanini. 2013. Variation in analytic causative constructions: a view on German and Romance. Journal of Comparative Germanic Linguistics 16. 209-230. https://doi.org/10.1007/s10828-014-9059-5.

Polinsky, Maria and Eric Potsdam. 2001. Long-distance agreement and topic in Tsez. Natural Language \& Linguistic Theory 19. 583-646. https://doi. org/10.1023/A:1010757806504.

Preminger, Omer. 2014. Agreement and its failures. MIT Press.

Sheehan, Michelle. 2011. A note on Case-assignment to CP. Snippets 24. 18-19.

Sheehan, Michelle. 2019. Passives and causatives in Romance: Puzzles and explanations. Invited plenary at Romanian and the Romance languages: The 18th international conference of the Department of Linguistics, University of Bucharest, November 2018. 
Sheehan, Michelle \& Anna Pineda. 2019. Transitive-sensitive causatives in Romance: Evidence for dependent case? . Anglia Ruskin-Cambridge Romance Linguistics Seminars for Easter Term. University of Cambridge, Cambridge, 14 February 2019.

Solà, Joan. 1994. Sintaxi normativa: estat de la qüestió. Barcelona: Empúries. Stowell, Timothy. 1981. Origins of phrase structure. MIT PhD dissertation.

Torrego, Esther. 1998. The dependencies of objects. Cambridge: The MIT Press.

Vikner, Sten. 1995. Verb movement and expletive subjects in the Germanic languages. Oxford: Oxford University Press.

Vikner, Sten. 2017. Germanic verb particle variation. In Enoch Aboh, Eric Haeberli, Genoveva Puskás, Manuela Schönenberger (eds.), Elements of Comparative Syntax - Theory and Description, 371-398. Berlin: Mouton de Gruyter.

Villalba, Xavier. 1992. Case, Incorporation, and Economy: An Approach to Causative Constructions. Calalan Working Papers in Linguistics 1. 345-389.

Yip, Moira, Joan Maling \& Ray Jackendoff. 1987. Case in tiers. Language 63. 217-250. https://doi.org/10.2307/415655.

Zaring, Laurie. 1992. French ce as a clausal determiner. Probus 4. 53-80. https:// doi.org/10.1515/prbs.1992.4.1.53. 